\title{
A Content Analysis of the Reading Activities in "Bright 2" an English Textbook for Junior High School Students
}

\author{
${ }^{1}$ Sucipto Sucipto, ${ }^{2}$ Septian Dwi Cahyo \\ ${ }^{1}$ Central China Normal University \\ ${ }^{2}$ Universitas Ahmad Dahlan \\ e-mail: sucipto@pbi.uad.ac.id.
}

\begin{abstract}
This study aimed to analyze the reading activities in "Bright 2", an English textbook for grade VIII students of junior high school in Indonesia, by using Bloom's revised taxonomy. A content analysis was conducted to achieve the research purpose. The findings show that the textbook has dominant reading activities especially on the cognitive process of "analyze" and "apply" aspects mounting to $27 \%$ and $21 \%$ respectively out of the total 145 reading activities. Meanwhile, the number of the higher and lower cognitive processes in this textbook is categorized balanced on the score of $49 \%$ of higher order thinking skills and $51 \%$ of the lower ones. There is a slight difference between the number of higher thinking skills and lower thinking skills since most reading activities found are on "analyze" aspect, which belong to the higher thinking skills while the second most frequent reading activities are found on "apply" aspect, which are lower thinking skills. However, "apply" and "analyze" aspects are placed at the 3rd and 4th in the taxonomy, which means that the textbook emphasizes the middle cognitive thinking process of Bloom's revised taxonomy, which is formed by "apply" and "analyze" thinking process.
\end{abstract}

Keywords: reading activities, EFL textbook, Bloom's revised taxonomy, content analysis

How to Cite: Sucipto, S., \& Cahyo $_{2}$ S. D. (2019). A content analysis of the reading activities in "Bright 2" an English textbook for junior high school students. English Language Teaching Educational Journal, 2(1), 13-21.

\section{INTRODUCTION}

The most commonly used teaching material is textbooks. As textbooks are developed to implement the curriculum ${ }_{2}$ they will provide structured learning objectives, learning activities, learning materials, and learning approaches as well so that they will improve students' thinking structure or cognitive achievement. Textbook is very helpful for teachers in conducting the teaching and learning process (Wen-Cheng, Chien-Hung, \& Chung-Chieh, 2011).

Indonesia's current curriculum, Kurikulum 2013 (K13), is intended to make Indonesian students be productive, creative, innovative, and effective by empowering and integrating attitudes, skills $s_{2}$ and knowledge (Departement Pendidikan Nasional, 2003). The significant differences of K13 and the previous curriculum are: $\mathrm{K} 13$ is balancing both hard-skills and soft-skills in the curriculum level. Textbooks under this curriculum are developed based on activities for middle school, and integrated thematic based ones for the elementary school level. In addition, they use a scientific learning approach and employ summative and formative assessment (Gunawan and Daud, 2018). 
The K13 demands the usage of an activities based textbook. The book design is intended to allow students to acquire knowledge as they know what, why, and how to solve the problems along the activities, thus the received information is meaningful for them (Departement Pendidikan Nasional, 2003).

As English is a compulsory subject in Indonesia, the English textbook should also be developed based on the curriculum. The learning of English as a foreign language in Indonesia needs a specific context to be meaningful. It also needs an activity-based book which can help the process of acquiring English inherent with the current curriculum. The activities meant here are the ones which provide hands-on experience to students in their process of acquiring knowledge and information with direct experience. In addition to providing direct experience, the activities are also expected to form a cognitive mindset in the students, i.e. activities which provide guidelines in the cognitive development of the students. Due to these considerations, activities are central aspects of a textbooks. Activities provided in textbooks are important aspects in developing students' thinking skills (Assaly \& Igbaria, 2014). Therefore, textbook plays a vital role in achieving the curriculum goal, with textbook needed to contribute to develop the student's creative thinking (Fatimah, 2018).

Boraie (2013) argues that teaching in English classes should focus on fostering student thinking as well as language content, outcomes, and learning activities. This argument is implemented in K13 in which the learning activities are student-centered learning. Consequently, the textbooks are developed applying activity-based not content-based.

Bright 2 is one among numerous English textbooks which are based on curriculum 2013 in the market. It is published by Erlangga which is one of the trusted educational textbook publishers in Indonesia. Since it is widely used in English language teaching in junior high schools in Indonesia, it is essential to analyze the activities in Bright 2 textbook analyzing whether or not the activities can develop students' higher thinking skills.

As the development of curriculum 2013 is based on Bloom's revised taxonomy, so that this study is aimed to analyze the activities in Bright 2 textbook using Bloom's revised taxonomy.

\section{Reading Activities in Textbooks}

Nordquist (2015) defines reading as the process of extracting meaning from a written or printed text. Reading is also a skill of communication. Grabe and Stoller (2002) define reading as the ability to draw meaning from the printed page and interpret this information appropriately. It is a process of understanding the message which is influenced by one's knowledge. Readers may be told that they have read if they are able to comprehend the passage about. Therefore they obtain such knowledge or information from it.

Activities are very significant in controlling learners' thinking. They are also essential tools for examining students' understanding of the learning material and assessing what levels of thinking students are using in the learning process (Assaly, I., \& Igbaria, A. K., 2014). 
The textbook is commonly used by the teacher in the classroom as supporting media in language teaching. Textbooks contain teaching material, activities to enhance students' knowledge, and evaluation. Using a textbook for classroom teaching gives a clear view of the teaching objectives, since it is developed based on standardized curriculum by government. Textbooks provide structuralized teaching materials. Harmer (2001) stated in order to be a success in learning English students need to be motivated, be exposed to language, given a chance to use the target language as much as possible. English textbooks provide learning objectives, teaching materials, language focus, task, activities and evaluation which give students familiar with the target language.

Textbook are wrritten to support the teaching and learning process. Cunningsworth (1995) stated textbooks or coursebooks are best seen as a resource of achieving objectives that have already been set in terms of learner needs. Teachers used materials in many different ways. According to Tomlinson (2012), a textbook designed for providing teaching materials of language learning course as much as possible so it will be the base of language teaching and learning process. Murray and Christison (2011) defined textbooks as all types of published materials to give students more opportunities to learn. Consequently, the textbook will be designed based on the current implemented curriculum in a country.

Richards (2001) stated textbooks as a commercial textbook,workbook, cassettes, CD's, and teachers' guide perhaps are the commonest teaching material in language teaching. Further, Brown (2001) stated that teachers can find learning material clear and most common in a textbook. Thus, the textbook will effectively support the teacher and the language learning process since it is available in the market and has a lot of varieties.

Research on EFL/ESL textbooks has been a concern for both researchers and teachers. The textbook is not only designed for one-time usage or to maintain the sustainability of it but the material should also be contextual along the time. The analysis of the Indonesian textbook comparing K13 and previous curriculum (KTSP/ school based curriculum) shows that there are significant differences and development on the textbooks' content (Hanifa, 2018). Textbooks from the previous curriculum can be adapted for the current curriculum by revising the content with contemporary contexts and needs. For example, the KTSP textbooks had much more authentic materials while in K13 have limited authentic materials (Hanifa, 2018). The evaluation and development should become a continuous process as well as education. The problem within the textbook is not always covering students' needs, nor does it meet the instructor's needs (Abdelrahman, 2014; Bouzid, 2017; Gulzar \& Multan, 2017). Therefore teachers need to revisit the textbook to make it suitable for teaching in the classroom.

\section{Bloom's Taxonomy and Bloom's Revised Taxonomy}

Activities in the textbook may direct students to develop creative thinking. It is a part of the higher-order thinking skills as stated in Bloom's cognitive taxonomy, which is widely known in education. It is a general 
taxonomy that describes six levels for examining the fulfillment of the goals of learners' cognitive domains: knowledge, comprehension, application, analysis, synthesis, and evaluation. As a result, it has become a tool to deliver learning objectives and also analysis for research (Assaly \& Igbaria, 2014). Furthermore, the taxonomy has been revised by Anderson, Krathwohl, et al., in 2001 (Krathwohl, 2002). The earlier taxonomy covered a single dimension of knowledge and became the base for developing learning evaluations, tests, activities, and objectives. However, on the process, the given objectives or evaluation are often assessed at the higher level of the taxonomy only and missed the intended level. The revised version by Anderson, Krathwohl, et al. changed the object-based taxonomy into process-based. Therefore, the terms or names for knowledge, comprehension, application, analysis, synthesis, and evaluation aspects are renamed into remember, understand, apply, analyze, create and evaluate respectively; from nouns into verbs. The change implicitly stated that cognitive was not a product but a process, therefore the new naming used verb. Furthermore, the revised taxonomy is also re-arranged the create taxonomy as the highest process switching it into "evaluate". The taxonomy also revamped into two dimensions; cognitive process dimension and knowledge dimension. Table 1 shows the level of cognitive process dimension level on the bloom's revised taxonomy.

Table 1. Cognitive process dimension level on Bloom's revised taxonomy (Krathwohl, 2002)

\begin{tabular}{cl}
\hline $\begin{array}{c}\text { Cognitive process dimension } \\
\text { level }\end{array}$ & \multicolumn{1}{c}{ Definition } \\
\hline Remember & $\begin{array}{l}\text { Retrieve relevant knowledge from long- } \\
\text { term memory } \\
\text { Make meaning from instructional } \\
\text { messages, including oral, written, and } \\
\text { graphic communication long-term } \\
\text { memory } \\
\text { Do or employ a process in a certain } \\
\text { situation }\end{array}$ \\
Apply & $\begin{array}{l}\text { Break materials into parts and determine } \\
\text { how the parts relate } \\
\text { Analyze } \\
\text { Evaluate }\end{array}$ \\
standards \\
Create & $\begin{array}{l}\text { Set elements together to form a coherent } \\
\text { or functional whole; we organize elements } \\
\text { into a new pattern or structure }\end{array}$ \\
\hline
\end{tabular}

Throughout the years, there are a lot of researches on the EFL textbooks which are based on the revised taxonomy. The analysis on textbook evaluation questions, testing question, reading comprehension questions, and language 
activities are analyzed by using the taxonomy to represents the cognitive process within the subjects (Abdelrahman, 2014; Assaly \& Igbaria, 2014; Ismail \& Hanim, 2018; Putri \& Komariah, 2018; Soleimani \& Kheiri, 2016; Tarman \& Kuran, 2015; Zareian, Davoudi, Heshmatifar, \& Rahimi, 2015).

There are many textbooks in the market that can be used for the teaching process, and teachers need to choose which textbook is most suitable to be used for the teaching process. However, most teachers are very dependent on the textbook.

This research analyzed Bright 2; An English Course for Junior High School Students textbook which is one among numerous K13 based English textbooks in the market. It aimed at analyzing to what extent the textbook encourages students to think under Higher Order Thinking Skills (HOTS) and was done by examining and assessing the total number of the reading activities in the intended textbook. As K13 demands the textbook to be based on activities to develop the students' knowledge, therefore, to determine the cognitive process level of the activities in Bright 2 textbook, the analysis of the study was conducted based on Bloom's Revised Taxonomy (BRT).

\section{RESEARCH METHOD}

This research applied content analysis research type investigating the level of the cognitive domains of the reading activities in Bright 2 textbook. There were 19 chapters with 145 reading activities in the textbook. These data were listed, reviewed and classified based on Bloom's Revised Taxonomy. In addition, an English teacher was invited to conduct the data validation. Afterward, the classified data were calculated and compared to identify the dominant cognitive process in the activities.

\section{FINDINGS AND DISCUSSION}

To achieve the objective of the research, the researcher collected and analyzed the content of the Bright 2 textbook using Bloom's Revised Cognitive Taxonomy. There were 145 reading activities on the textbook collected from 19 units. Table 2 describes the frequencies and percentages of each cognitive process.

Table 2. Frequencies and percentages of cognitive process

\begin{tabular}{lcc}
\hline $\begin{array}{c}\text { Cognitive } \\
\text { process }\end{array}$ & Quantity & Percentages \\
\hline Remember & 23 & $16 \%$ \\
Understand & 20 & $14 \%$ \\
Apply & 30 & $21 \%$ \\
Analyze & 39 & $27 \%$ \\
Evaluate & 6 & $4 \%$ \\
Create & 27 & $18 \%$ \\
Total & 145 & $100 \%$ \\
\hline
\end{tabular}


Table 2 shows the analysis of the reading activities in the textbook based on Bloom's Revised Taxonomy classification. The table shows that the most dominant cognitive process was the "analyze" process by $27 \%$ (39 activities 0 and followed by the "apply" process reaching the percentage of $21 \%$ (30 activities). This "analyze" category included the cognitive processes of "differentiating", "organizing", and "attributing". Therefore, objectives classified as "analyze" involve learning activities determining the relevant or essential pieces of a message (differentiating), how the pieces of a word are configured (organizing), and the underlying purpose of the message (attributing) (Mayer, 2001). Meanwhile, the least cognitive process on reading activities was found at the "evaluate" process. "Evaluate" is one of the complex cognitive processes (Raths, James, 2002). Under "evaluate" category, it was found out that there were only 6 activities or $4 \%$. In other words, there were only a few activities in the textbook which require students to do evaluation exercises.

As explained previously, the classification of Bloom's cognitive process is divided into two groups, i.e. higher and lower cognitive process. The higher cognitive process includes "analyze", "evaluate" and "create", while "remember", "understand" and "apply" are grouped into lower thinking processes (Soleimani \& Kheiri, 2016). Using this classification, the data analysis shows that the number of the higher cognitive process level of reading activities in Bright 2 is less compared to the lower level thinking process. The higher cognitive process level is $49 \%$ with 72 reading activities while the lower cognitive process level is $51 \%$ with 73 reading activities.

The distribution of the activities between higher and lower cognitive processes has almost the same number which represents the balance of both cognitive process levels. However, the most dominant cognitive process in the textbook is "analyze" and "apply" with $27 \%$ and $21 \%$ consecutively which represents that the textbook's intended goal is to develop students' skills to use English concepts appropriately. This is in accordance with the objective that the textbook is designed for English foreign learners.

Considering the results above, it suggested that Bright 2 should be able to encourage students to have a higher cognitive process because the higher cognitive process will lead the success to achieve the curriculum goal. It's because Bright 2 is designed for the 8 graders of junior high school so the researchers think that the introduction to create reading activities is needed to develop students' cognitive dimension process into the higher process. Besides, the students' success can be identified by classifying and improving their level of cognitive development (Ismail \& Hanim, 2018). Bloom's Taxonomy has been broadly used as an essential topic for training thinking skills to stimulate higher order thinking in education such as analyzing and evaluating rather than other skills (Soo, Hasan, Jangga, \& Mat, 2015).

\section{CONCLUSION}

The results show that Bright 2; An English Course for Junior High School Students textbook emphasizes the middle-lower cognitive process as the majority 
of the activities are on "apply" and "analyze" cognitive process. However, most reading activities appear in "analyze" cognitive process, which belongs to higher cognitive process. The reading activities are at the lower thinking process as it has $51 \%$ with 73 reading activities. The higher thinking process has $49 \%$ with 72 reading activities. There is a slight difference between the number higher thinking process and lower thinking process, since most reading activities are on "analyze" which belongs to higher thinking process while the second most frequent reading activities are "apply", which belongs to the lower thinking process. Meanwhile, "apply" and "analyze" is placed on the 3rd and 4th in the taxonomy. Thus, it could be concluded that the textbook emphasizes the middle cognitive thinking process of Bloom's revised taxonomy, which is formed by "apply" and "analyze" thinking process.

\section{REFERENCES}

Abdelrahman, M. S. H. B. (2014). An analysis of the tenth grade English language textbooks questions in Jordan based on the revised edition of Bloom's Taxonomy. Journal of Education and Practice, 5(18), 139-151.

Assaly, I., \& Igbaria, A. K. (2014). A content analysis of the reading and listening activities in the EFL textbook of master class. Education Journal Ibtihal Assaly Education Journal, 3(2), 24-38. https://doi.org/10.11648/j.edu.20140302.11.

Boraie, Deena. (2013). 8 current trends in teaching and learning EFL/ESL. http://blog.tesol.org/8-current-trends-in-teaching-and-learning-eflesl/ accessed on 18/1/2016 at 5.56pm

Bouzid, H. A. (2017). An evaluation of selected Moroccan ELT textbooks: a standards-based approach perspective. Indonesian Journal of Applied Linguistics, 7(1), 229. https://doi.org/10.17509/ijal.v7i1.6879

Brown, H. Douglas. (2001). Teaching by principle (An interactive approach to language pedagogy, second Eeition). San Francisco: Addison Wesley Longman,Inc.

Cunningsworth, Alan. (1995). Choosing your coursebook. Oxford; Macmillan Publishers.

Departement Pendidikan Nasional. (2003). Sistem pendidikan nasional. In Undang-undang RI No. 20 tahun 2003.

Fatimah, N. (2018). Students' needs for academic writing at the English education department. English Language Teaching Educational Journal, 1(3), 161-175. 
Grabe, William and Stoller, L. (2002). Teaching and researching reading. London: Pearson Education Longman.

Gulzar, S., \& Multan, N. (2017). An evaluation of English textbook at matriculation level in Multan division, Pakistan. European Journal of English Language Teaching, 2(4), 114-134. https://doi.org/10.5281/zenodo.835635

Hanifa, R. (2018). EFL published materials : An evaluation of English textbooks for junior high school in Indonesia. Advances in Language and Literary Studies, 9(2009), 166-174. https://doi.org/10.7575/aiac.alls.v.9n.2p.166

Harmer, Jeremy. (2009). How to teach English; New Edition. Saffron walden; Pearson Longman.

Gunawan, H. and Daud, A. (2018). The implementation of 2013 curriculum in English teaching: Stories from rural Areas. English Language Teaching Educational Journal, 1(2), 65-75.

Ismail, Y. M. A. R., \& Hanim, H. (2018). Analyzing the reading questions of AP12 textbook according to analyzing the reading questions of AP12 textbook according to Bloom's Taxonomy. International Journal of Education, Psychology and Counseling, 3(22), 84-94.

Krathwohl, D. R. (2002). A revision of Bloom's Taxonomy: An overview Benjamin S. Bloom, University of Chicago. Theory into Practice, 41(4), 212-218.

Mayer, Richard, E. (2002). Rote versus meaningful learning, Theory into Practice, Volume 41, Number 4, Autumn, 226-232.

Murray, Denise E. and Christison, MaryAnn. (2011). What English language teachers need to know volume II: Facilitating Learning. New York; Routledge.

Nordquist, Richard. (2015). Reading glossary of grammatical and rhetorical terms. http://grammar.about.com/od/rs/g/readingterm.htm accessed on 30 January 2016 at 1.45 PM

Putri, M. A., \& Komariah, E. (2018). A content analysis of activities in English textbook "When English Rings A Bell." Research in English and Education (READ), 3(2), 147-153.

Raths, James. (2002). Improving instruction. Theory into Practice, Volume 41, Number 4, Autumn, 233-237. 
Richards, Jack C. (2001). Curriculum development in language teaching. Cambridge; Cambridge University Press.

Soleimani, H., \& Kheiri, S. (2016). An evaluation of TEFL postgraduates' testing classroom activities and assignments based on Bloom's revised taxonomy. Theory and Practice in Language Studies, 6(4), 861-869. https://doi.org/10.1016/j.spa.2013.01.004

Soo, K. Y., Hasan, N. H., Jangga, R., \& Mat, K. S. N. I. (2015). Innovating with HOTS for the ESL reading class. English Language Teaching, 8(8), 10.

Tarman, B., \& Kuran, B. (2015). Examination of the cognitive level of questions in social studies textbooks and the views of teachers based on Bloom taxonomy. Educational Sciences: Theory \& Practice, 15(1), 213-222. https://doi.org/10.12738/estp.2015.1.2625

Tomlinson, Brian. (2011). Materials development in language teaching: Second edition. Cambridge; Cambridge University Press.

Wen-Cheng, W., Chien-Hung, L., \& Chung-Chieh, L. (2011). Thinking of the textbook in the ESL/EFL classroom. English Language Teaching, 4 (2), 91. https://doi.org/10.5539/elt.v4n2p91

Zareian, G., Davoudi, M., Heshmatifar, Z., \& Rahimi, J. (2015). An evaluation of Questions in Two ESP coursebooks Based on Bloom's new taxonomy of cognitive learning domain. International Journal of Education and Research, 3(8), 313-326. https://doi.org/10.1016/j.spa.2013.01.004 